Perwira Journal of Science and Engineering (PJSE)

E-ISSN : 2775-8486

Volume 1 Nomor 1

Februari 2021

\title{
ANALISIS PROSES PEMBERDAYAAN UMKM AGRIBISNIS BERBASIS CSR
}

\author{
Bayu Mahendra ${ }^{(1)}$, Senti Nistiani( ${ }^{(2)}$ \\ (1), (2)Universitas Perwira Purbalingga \\ 31bayumahendra@gmail.com
}

\begin{abstract}
ABSTRAK
Pemberdayaan adalah sebuah proses dan tujuan. Sebagai proses pemberdayaan adalah serangkaian kegiatan untuk memperkuat kekuasaan atau keberdayaan kelompok lemah dalam masyarakat, termasuk individu-individu yang mengalami masalah kemiskinan.. Penelitian ini merupakan penelitian deskriptif dengan metode kualitatif. Pengumpulan data dilakukan dengan indepth interview, observasi partisipasi, dan data sekunder. Penelitian ini berfokus pada kajian proses pemberdayaan melalui program CSR yang dilakukan PT. Angkasa Pura I terhadap Usaha Mikro Kecil dan Menengah (UMKM) dibidang Agribisnis Proses pemberdayaan melalui program CSR yang dilaksanakan PT. Angkasa Pura I kepada UMKM telah dilaksanakan sesuai dengan aturan dan pedoman yang berlaku. Perkembangan UMKM yang memanfaatkan program CSR dari PT. Angkasa Pura I sudah berjalan dengan baik yang ditandai dengan mulai berkembangnya asset usaha hingga pola berfikir dalam berusaha.
\end{abstract}

Kata Kunci : Pemberdayaan, Agribisnis, CSR, UMKM

\section{PENDAHULUAN}

Pemberdayaan dapat diartikan sebagai tujuan dan proses. Sebagai tujuan, pemberdayaan adalah suatu keadaan yang ingin dicapai, yakni masyarakat yang memiliki kekuatan atau kekuasaan dan keberdayaan yang mengarah pada kemandirian. Sebagai proses, pemberdayaan masyarakat merupakan upaya untuk memandirikan masyarakat lewat perwujudan potensi kemampuan yang mereka miliki (Sumodiningrat, 1999). Program Desa Wisata Rempah dan Buah merupakan bentuk pemberdayaan di mana apa yang sudah diberikan tidak habis melainkan sebuah embrio yang pada akhir nya mendapatkan sesuatu dalam jangka panjang bahkan berkembang dan berkelanjutan, yang diberdayakan adalah pertama, dari segi kapasitas SDM di mana yang dulunya tidak mengerti menjadi mengerti, kedua daya dukung (bentuk fisik), tampak nyata yakni bantuan bibit yang dulunya hanya mempunyai bibit sedikit menjadi banyak, ketiga ekonomi yakni pendapatannya meningkat.

Untuk meningkatkan kesejahteraan sosial masyarakat pemerintah mencanangkan program Corporate Social Responsibility (CSR) bagi perusahaan mulai tahun 2007 yang tertuang dalam Undang-Undang Nomor 40 Tahun 2007 Bab V pasal 74 ayat 1 , yang menyebutkan bahwa perseroan yang menjalankan usahanya di bidang dan atau berkaitan dengan sumberdaya alam wajib melaksanakan tanggung jawab sosial dan lingkungan Corporate Social Responsibility (CSR). Angkasa Pura I yang merupakan BUMN juga memiliki tanggung jawab untuk melaksanakan program Corporate Social Responsibility (CSR), hal ini diatur dalam PER-03/MBU/12/2016. 
Perwira Journal of Science and Engineering (PJSE)

E-ISSN : 2775-8486

Volume 1 Nomor 1

Februari 2021

Melalui program tersebut dirumuskan kembali mekanisme upaya peningkatan kesejahteraan sosial masyarakat yang melibatkan unsur perusahaan, masyarakat dan pemerintahan desa mulai dari tahap perencanaan, pelaksanaan, hingga pemantauan dan evaluasi. Melalui proses pemberdayaan partisipatif, kesadaran kritis, kemandirian masyarakat dan peran perusahaan, tujuannya untuk memberikan kontribusi pembangunan yang berkelanjutan, kesehatan dan kesejahteraan sosial, dengan kata lain CSR PT. Angkasa Pura I dapat dijadikan sebagai salah satu sumber pembiayaan pembangunan masyarakat.

Setiap UMKM tentunya memiliki harapan untuk dapat mengembangkan usaha menjadi lebih besar dan lebih baik, begitu juga pada UMKM Madu Hutan Raya dan Mina Kembar. Pada kenyataanya untuk dapat mengembangkan usahanya, UMKM harus kuat secara modal, inovasi dan SDM hal tersebut masih belum terlihat pada UMKM Madu Hutan Raya dan Mina Kembar.

Program CSR PT. Angkasa Pura I telah dimulai sejak tahun 2003 dengan mengusung Program Kemitraan dan Bina Lingkungan (PKBL). PKBL adalah suatu jenis program Tanggung Jawab Sosial/Corporate Social Responsibility (CSR) yang hanya ada di Badan Usaha Milik Negara (BUMN) saja. PKBL terdiri dari dua jenis Program yakni Program Kemitraan (PK) dan Bina Lingkungan (BL). PK adalah suatu program yang mewajibkan BUMN untuk memberikan pinjaman usaha dan pembinaan kepada Usaha Mikro Kecil dan Menengah (UMKM). Lalu BL adalah sebuah program yang diberikan melalui bantuan dana untuk keperluan program/kegiatan pengembangan masyarakat. Fokus area kedua program tersebut adalah wilayah lokasi dimana suatu BUMN beroperasi. Untuk meningkatkan kesejahteraan sosial masyarakat pemerintah mencanangkan program Corporate Social Responsibility (CSR) bagi perusahaan mulai tahun 2007 yang tertuang dalam Undang-Undang Nomor 40 Tahun 2007 Bab V pasal 74 ayat 1, yang menyebutkan bahwa perseroan yang menjalankan usahanya di bidang dan atau berkaitan dengan sumberdaya alam wajib melaksanakan tanggung jawab sosial dan lingkungan Corporate Social Responsibility (CSR). PT ANGKASA PURA I juga memiliki tanggung jawab untuk melaksanakan program Corporate Social Responsibility (CSR), hal ini diatur dalam PER03/MBU/12/2016. Melalui program tersebut dirumuskan kembali mekanisme upaya peningkatan kesejahteraan sosial masyarakat yang melibatkan unsur perusahaan, masyarakat dan pemerintahan desa mulai dari tahap perencanaan, pelaksanaan, hingga pemantauan dan evaluasi. Melalui proses pemberdayaan partisipatif, kesadaran kritis, kemandirian masyarakat dan peran perusahaan, tujuannya untuk memberikan kontribusi pembangunan yang berkelanjutan, kesehatan dan kesejahteraan sosial, dengan kata lain CSR PT. Angkasa Pura I dapat dijadikan sebagai salah satu sumber pembiayaan pembangunan masyarakat.

\section{Tinjauan Pustaka}

Secara konseptual pemberdayaan atau pemberkuasaan (empowerment), berasal dari kata 'power' (kekuasaan atau keberdayaan). Pemberdayaan sebagai sebuah proses perubahan kemudian memiliki konsep yang bermakna. Dengan kata lain, kemungkinan terjadinya proses pemberdayaan sangat tergantung pada dua hal, yaitu (pertama) bahwa kekuasaan dapat berubah.Jika kekuasaan tidak dapat berubah, pemberdayaan tidak mungkin terjadi dengan cara apapun. (Kedua) bahwa kekuasaan 
Perwira Journal of Science and Engineering (PJSE)

E-ISSN : 2775-8486

Volume 1 Nomor 1

Februari 2021

dapat diperluas. Konsep ini menekankan pada pengertian kekuasaan yang tidak statis, melainkan dinamis (Suharto, 2017).

Pemberdayaan menunjuk pada kemampuan orang, khususnya kelompok rentan dan lemah, sehingga mereka memiliki kekuatan atau kemampuan dalam (a) memenuhi kebutuhan dasarnya sehingga mereka memiliki kebebasan (freedom), dalam arti bukan saja bebas mengemukakan pendapat, melainkan bebas dari kelaparan, bebas dari kebodohan, bebas dari kesakitan; (b) menjangkau sumber-sumber produktif yang memungkinkan mereka dapat meningkatkan pendapatannya dan memperoleh barangbarang dan jasa-jasa yang mereka perlukan; dan (c) berpartisipasi dalam proses pembangunan dan keputusan-keputusan yang mempengaruhi mereka. Menurut Ife sebagaimana ditulis oleh Suharto menjelaskan bahwa pemberdayaan bertujuan untuk meningkatkan kekuasaan orang-orang yang lemah atau tidak beruntung. Menurut Parsons sebagaimana ditulis oleh Suharto menjelaskan bahwa pemberdayaan adalah sebuah proses dengan mana orang menjadi cukup kuat untuk berpartisipasi dalam, berbagai pengontrolan atas, dan mempengaruhi terhadap, kejadian-kejadian serta lembaga-lembaga yang mempengaruhi kehidupannya. Pemberdayaan menekankan bahwa orang memperoleh keterampilan, pengetahuan, dan kekuasaan yang cukup untuk mempengaruhi kehidupannya dan kehidupan orang lain yang menjadi perhatiannya. Sedangkan menurut Swift dan Levin sebagaimana ditulis oleh Suharto menjelaskan bahwa pemberdayaan menunjuk pada usaha pengalokasian kembali kekuasaan melalui pengubahan stuktur sosial. Dengan demikian, pemberdayaan adalah sebuah proses dan tujuan. Pemberdayaansebagai proses, pemberdayaan adalah serangkaian kegiatan untuk memperkuat kekuasaan atau keberdayaan kelompok lemah dalam masyarakat, termasuk individu-individu yang mengalami masalah kemiskinan. Sedangkan pemberdayaan sebagai tujuan, maka pemberdayaan menunjuk pada keadaan atau hasil yang ingin dicapai oleh subuah perubahan sosial; yaitu masyarakat yang berdaya, memiliki kekuasaan atau mempunyai pengetahuan dan kemampuan dalam memenuhi kebutuhan hidupnya baik yang bersifat fisik, ekonomi, maupun sosial seperti memiliki kepercayaan diri, mampu menyampaikan aspirasi, mempunyai mata pencaharian, berpartisipasi dalam kegiatan sosial, dan mandiri dalam melaksanakan tugas-tugas kehidupannya. Pengertian pemberdayaan sebagai tujuan seringkali digunakan sehingga indikator keberhasilan pemberdayaan sebagai sebuah proses.

\section{METODE}

Penelitian ini dilakukan di Ring I Bandar Udara Adisucipto yaitu daerah lingkungan kerja bandar udara (DLKR) Yogyakarta yaitu 7 hingga $15 \mathrm{~km}$ dari bandar udara dan ditujukan pada UMKM yang menjadi mitra PT. Angkasa Pura I yang bergerak dibidang agribisnis. Penelitian ini merupakan penelitian deskriptif dengan metode kualitatif. Pengumpulan data dilakukan dengan indepth interview, observasi partisipasi, dan data sekunder. Data yang dikumpulkan berupa catatan yang ditulis tangan, gambar, foto, objek, suara dan gerak tubuh (gesture). Sumber Data untuk mendukung penelitian ini dapat diperoleh dari dua sumber, yaitu data primer dan data sekunder.

Data Primer, yaitu data yang diperoleh langsung dari sumbernya yaitu UMKM mitra maupun PT. Angkasa Pura I yang didapat melalui wawancara dan observasi secara langsung. 
Perwira Journal of Science and Engineering (PJSE)

E-ISSN : 2775-8486

Volume 1 Nomor 1

Februari 2021

Data Sekunder, yaitu data yang sudah ada dalam pengumpulannya, diperoleh dari instansi terkait dalam penelitian, yaitu laporan dan catatan program CSR PT. Angkasa Pura I. Dalam pemilihan informasi ini dipilih 2 informan mitra binaan yang telah mengikuti kegiatan pembinaan dan memiliki usaha yang bergerak dibidang agribisnis dengan tujuan agar memperoleh informasi yang variatif dan menyeluruh. Data yang diperoleh di lapangan selanjutnya disajikan dengan mendeskripsikan temuan penelitian secara sistematis, faktual, dan akurat disertai dengan petikan hasil wawancara dengan tiap-tiap informan.

Subjek penelitian dipilih dengan metode purposive sampling yang dipilih tidak secara acak melainkan didasarkan pada suatu pertimbangan tertentu yang dibuat oleh peneliti sendiri, yaitu sesuai dengan kriteria inklusi yang telah ditetapkan peneliti.

Tabel 1 Informasi yang Dibutuhkan dan Status Informan

\begin{tabular}{|c|c|c|}
\hline $\begin{array}{c}\text { Informasi yang } \\
\text { Dibutuhkan }\end{array}$ & Informan (Status) & Jumlah \\
\hline \multirow{3}{*}{$\begin{array}{c}\text { Pelaksanaan Program } \\
\text { Corporate social } \\
\text { Responsibility (CSR) oleh } \\
\text { PT Angkasa Pura I }\end{array}$} & $\begin{array}{l}\text { Divisi CSR PT } \\
\text { Angkasa Pura I }\end{array}$ & 7 orang \\
\hline & $\begin{array}{c}\text { Pemilik UMKM } \\
\text { Mina Kembar }\end{array}$ & 1 orang \\
\hline & $\begin{array}{c}\text { Pemilik UMKM } \\
\text { Madu Hutan Raya }\end{array}$ & 1 orang \\
\hline \multirow[t]{2}{*}{ Proses Pemberdayaan } & $\begin{array}{l}\text { Divisi CSR PT } \\
\text { Angkasa Pura I }\end{array}$ & \\
\hline & $\begin{array}{l}\text { Pemilik UMKM } \\
\text { Madu Hutan Raya } \\
\text { dan Mina kembar }\end{array}$ & \\
\hline Jumlah Informan & & 9 orang \\
\hline
\end{tabular}

Dalam penelitian ini penulis menganalisis data yang diperoleh dengan cara deskriptif kualitatif yaitu suatu cara menarik kesimpulan dengan memberikan gambaran atau menjabarkan terhadap data yang terkumpul dalam bentuk uraian kalimat sehingga pada akhirnya dapat mengantarkan pada kesimpulan. Langkahlangkah yang dilakukan adalah menajamkan analisis, menggolongkan atau pengkategorikan ke dalam tiap permasalahan melalui uraian singkat, mengarahkan, membuang yang tidak perlu, dan mengorganisasikan data sehingga dapat ditarik dan diverifikasi.

Reduksi data dilakukan dengan meringkas kembali catatan lapangan dengan memilih hal-hal yang pokok atau penting, yakni yang berkaitan dengan permasalahan yang menjadi fokus penelitian.

Dalam penelitian ini peneliti juga menggunakan teknik triangulasi dalam menentukan keabsahan sumber data. Triangulasi data diartikan sebagai pengecekan data dari berbagai sumber dengan berbagai cara, dan berbagai waktu. 
Perwira Journal of Science and Engineering (PJSE)

E-ISSN : 2775-8486

Volume 1 Nomor 1

Februari 2021

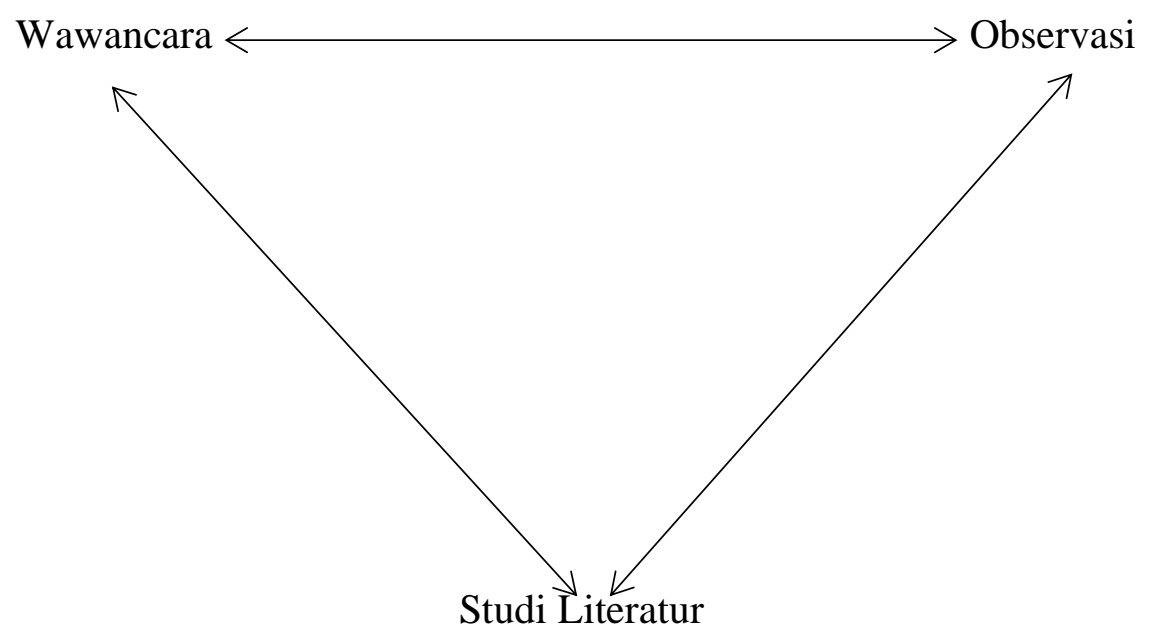

Gambar 1 Triangulasi Teknik Pengumpulan Data

Proses analisis data dilakukan sejak data-data diperoleh dengan menelaah seluruh data yang tersedia dari berbagai sumber, yaitu dari wawancara yang dilakukan, catatan lapangan, dokumen pribadi, gambar, dan sebagainya setelah dibaca, dipelajari, dan ditelaah, selanjutnya diambil sesuai dengan relevansi atau sesuai kebutuhan penelitian. Langkah selanjutnya adalah mengadakan reduksi data yang dilakukan dengan membuat abstraksi.

Abstraksi merupakan usaha membuat rangkuman inti proses dan pernyataan - pernyataan yang perlu dijaga sehingga tetap berada di dalamnya. Kemudian disusun dalam satuan-satuan yang dikategorikan dan diadakan pemeriksaan keabsahan data.

Data yang di reduksi antara lain seluruh data mengenai permasalahan penelitian. Data yang di reduksi akan memberikan gambaran yang lebih spesifik dan mempermudah peneliti melakukan pengumpulan data selanjutnya serta mencari data tambahan jika diperlukan. Semakin lama peneliti berada di lapangan maka jumlah data akan semakin banyak, semakin kompleks dan rumit. Oleh karena itu, reduksi data perlu dilakukan sehingga data tidak bertumpuk agar tidak mempersulit analisis selanjutnya. Tujuan peneliti menggunakan teknik triangulasi dalam penelitian ini adalah untuk menguji keabsahan data yang peneliti peroleh di lapangan dengan memanfaatkan sesuatu yang lain. Selain itu teknik tersebut dapat dipakai untuk keperluan pengecekan atau sebagai pembanding terhadap data, baik data dari hasil wawancara, observasi, dan dokumentasi. Dengan demikian teknik pengumpulan data yang digunakan dapat melengkapi dalam memperoleh data penelitian.

Bila dengan teknik pengujian kreadibilitas data tersebut menghasilkan data yang berbeda-beda maka peneliti melakukan diskusi lebih lanjut kepada sumber data yang bersangkutan atau yang lain, untuk memastikan data mana yang dianggap benar. Atau mungkin semuanya benar, karena sudut pandang berbeda-beda. 
Perwira Journal of Science and Engineering (PJSE)

E-ISSN : 2775-8486

Volume 1 Nomor 1

Februari 2021

\section{HASIL}

Gambaran Umum Subyek

UMKM Mina Kembar secara 6ocial6trative terletak di Dusun Candisingo, RT 1, RW 24, Madurejo, Prambanan, Sleman, Yogyakarta. UMKM yang berdiri sejak tahun 2006 ini mengusahakan budidaya perikanan, dengan jenis ikan yang di budidayakan adalah lele, nila dan gurameh. Ibu Valentina Wijayanti sebagai pemilik UMKM mengatakan bahwa usaha yang beliau rintis ini merupakan usaha yang sangat membutuhkan perputaran modal dan memiliki resiko yang tidak kecil.

UMKM Madu Hutan Raya berdiri sejak tahun 2013, UMKM yang bergerak dalam bidang pendistribusian dan penjualan madu hutan ini secara 6ocial6trative terletak di Rusunawa Dabag, Condongcatur, Depok, Kabupaten Sleman. Dalam kegiatan pemasaran yang dilakukan oleh UMKM Madu Hutan Raya tidak hanya dilakukan di Rusunawa Dabag saja, melainkan dipasarkan juga dengan cara berkeliling menggunakan speda motor yang telah di modifikasi.

Pelaksanaan Program CSR

Latar belakang perusahaan dalam melaksanakan program CSR salah satunya adalah sebagai bentuk realisasi dari salah satu misi perusahaan yaitu turut berkontribusi dalam menumbuhkan pendapatan masyarakat. Hal Ini seperti yang dikatakan Ibu Christine selaku staff divisi CSR yang menangani program kemitraan dengan pihak UMKM.

"Program CSR ini sangat membantu mas" program ini bertujuan agar usaha milik masyarakat DIY dapat maju sehingga perekonomian DIY juga berkembang, "untuk pelaksanaanya kita berdasarkan salah satu misi perusahaan yaitu ikut berkontribusi dalam menumbuhkan pendapatan masyarakat, terutama masyarakat sekitar "kita"

Sumber pendanaan program CSR PT. Angkasa Pura I berasal dari sebagian keuntungan perusahaan. Hal ini seperti yang disampaikan oleh Ibu Prastika selaku salah satu staff divisi $C S R$.

Sumber dana program ini murni dari CSR ya mas, jadi sebagian keuntungan perusahaan akan disisihkan untuk dana program seperti ini.

Program CSR tersebut merupakan wujud dari kepedulian PT. Angkasa Pura I terhadap kesejahteraan masyarakat sekitarnya. Untuk menyebarluaskan informasi program CSR, PT. Angkasa Pura I menggunakan website dengan tujuan agar banyak masyarakat yang mengetahui tentang adanya program yang bisa dimanfaatkan.Hal ini seperti disampaikan Ibu Prastika dalam mengkomunikasikan Program CSR kepada masyarakat. 
Perwira Journal of Science and Engineering (PJSE)

E-ISSN : 2775-8486

Volume 1 Nomor 1

Februari 2021

Kita ada iklannya di web, lalu dari mulut kemulut juga, selain itu jika ada event atau pameran BUMN masyarakat bisa tanya-tanya langsung mas

Pelatihan yang dilakukan oleh PT. Angkasa Pura I kepada UMKM memiliki tujuan yang penting, yaitu untuk dapat memperkuat UMKM dari segi manajemen, segi dm dan juga semangat berwirausaha. Hal ini seperti disampaikan Ibu Christine yang ditemui di ruang kerja divisi CSR PT Angkasa Pura I

Kalau tujuan kita pastinya ingin menguatkan UMKM dari segala segi ya mas, tapi kan semua kembali lagi kepada peserta pelatihan kita, ada yang ingin menerapkan atau tidak, ada yang serius menikuti pelatihan atau tidak, tapi untuk keseluruhan pelatihan saya rasa kalau diikuti secara serius hasilnya pasti akan baik

Dalam mengikuti program CSR dari PT. Angkasa Pura I, UMKM Mina Kembar mengikuti seluruh rangkaian proses pelaksanaan program, sehingga UMKM Mina Kembar dapat mengembangkan usahanya dan memanfaatkan dana pinjaman dengan baik. Ibu Valentina memberikan informasi mengenai rangkaian kegiatan yang dilakukan.

"Prosesnya itu dari awal ya mas, kalau dari awal itu saya kebetulan ketemu dengan salah satu staff CSR PT. Angkasa Pura I, kemudian memberi tahu ada program CSR yang memberi dana pinjaman lunak, pelatihan dan bantuan promosi juga, nahh ini menurut saya peluang mas, jadi saya bisa mengembangkan usaha saya ini mas. Oh kalau untuk proses programnya itu kita ikut pelatihan dulu mas, itu ya dilatih macem 2 mas mulai dari dasar bisnis sampai yang lain2, setelah pelatihan selesai baru dana kita terima dan ya saya gunakan to mas, untuk bikin kolam dulu, lalu yang lainya saya simpen pas kolam udah jadi saya belikan bibit, pakan dan lain 2 mas.

Sebelum mengikuti program CSR PT. Angkasa Pura I, UMKM Madu Hutan raya mempunyai masalah dalam membeli madu dari NTT dan Jawa hal ini dikarenakan modal yang dimiliki harus dapat membayar kontan madu yang akan dipasarkan oleh UMKM Madu Hutan raya. Proses pengemasan dan promosinya

"Waktu itu saya sedang lihat2 pameran BUMN mas, nah pas saya tanya2 ternyata ada program CSR ini, dan program ini juga menyediakan pelatihan dan stand khusus untuk promo produk, jadi saya langsung daftar aja gitu mas. Kalau untuk prosesnya ya mas ya kita diberi pelatihan manajemen dulu, supaya dana yang akan kita terima itu dapat kita gunakan secara baik mas, setelah pelatihan 3 hari di hotel apa ya lupa saya, baru kita mendapat dana CSR ini lalu ya sebisanya saya lakukan persis seperti yang di pelatihan itu mas 
Perwira Journal of Science and Engineering (PJSE)

E-ISSN : 2775-8486

Volume 1 Nomor 1

Februari 2021

pun masih sangat sederhana sehingga pendapatan yang diperoleh hanya sedikit dan sulit untuk mengembangkan usahanya. UMKM Madu Hutan Raya kemudian mencari informasi dan peluang yang dapat membantu mengembangkan usahanya. Bapak Waluyo selaku pemilik UMKM Madu Hutan Raya mengemukakan, bahwa:

Dari hasil observasi dan wawancara yang telah dilakukan dapat dilihat proses pemberdayaan yang berlangsung untuk UMKM yang mengikuti program kemitraan (CSR) dengan PT. Angkasa Pura I

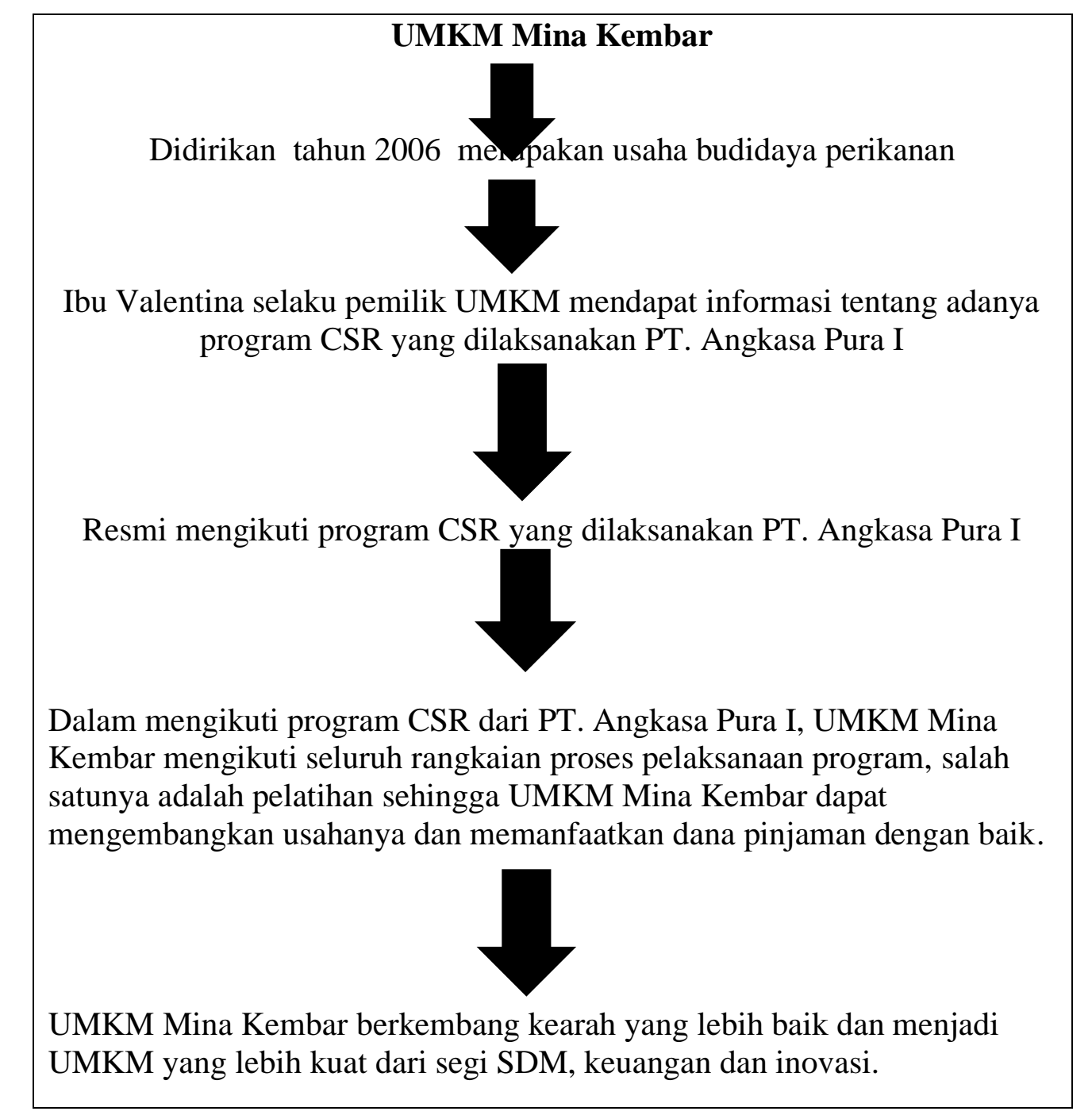

Gambar 2 Proses Pemberdayaan Pada UMKM Mina Kembar

\begin{tabular}{l|l|l}
\hline Uraian & \multicolumn{1}{|c}{ Sebelum Bergabung } & \multicolumn{2}{c}{ Sesudah Bergabung } \\
& $\begin{array}{l}\text { Belum mengetahui dasar bisnis, cara } \\
\text { pembuatan laporan keuangan yang } \\
\text { benar }\end{array}$ & $\begin{array}{l}\text { Dampak dari pelaksanaan } \\
\text { pelatihan bagi UMKM adalah } \\
\text { para pelaku UMKM menjadi lebih } \\
\text { memahami dasar bisnis, lebih } \\
\text { memahami pembuatan laporan }\end{array}$ \\
\hline
\end{tabular}


Perwira Journal of Science and Engineering (PJSE)

E-ISSN : 2775-8486

Volume 1 Nomor 1

Februari 2021

\begin{tabular}{|c|c|c|}
\hline & & $\begin{array}{l}\text { keuangan yang benar, lebih } \\
\text { bersemangat dalam } \\
\text { mengembangkan usahanya. }\end{array}$ \\
\hline $\begin{array}{l}\text { Kemampuan } \\
\text { SDM dalam } \\
\text { mengelola } \\
\text { keuangan dan } \\
\text { manajemen } \\
\text { usaha }\end{array}$ & $\begin{array}{l}\text { Tidak berani mengambil resiko, dan } \\
\text { dari segi pengelolaan keuangan masih } \\
\text { belum sempurna. }\end{array}$ & $\begin{array}{l}\text { Secara kemampuan juga terjadi } \\
\text { peningkatan, yaitu kemampuan } \\
\text { mengelola keuangan yang } \\
\text { menjadi semakin baik dan rapi, } \\
\text { kemampuan mengambil resiko } \\
\text { yang semakin matang dan } \\
\text { semangat berusaha yang } \\
\text { meningkat. }\end{array}$ \\
\hline $\begin{array}{l}\text { Jangkauan usaha } \\
\text { dan pemasaran }\end{array}$ & $\begin{array}{l}\text { Pangsa pasar tidak luas, sehingga } \\
\text { produktifitas yang didapat tidak } \\
\text { melgalami kenakan. }\end{array}$ & $\begin{array}{l}\text { Jangkauan usaha UMKM Mina } \\
\text { Kembar juga meluas dan di iringi } \\
\text { dengan peningkatan produktifitas }\end{array}$ \\
\hline $\begin{array}{l}\text { Motivasi dan } \\
\text { inovasi dalam } \\
\text { mengembangkan } \\
\text { usaha }\end{array}$ & $\begin{array}{l}\text { Tidak memiliki inovasi baru untuk } \\
\text { mengembangkan usaha. }\end{array}$ & $\begin{array}{l}\text { Mempunyai keinginan dan ide } \\
\text { baru dengan membuat rumah } \\
\text { makan kecil-kecilan yang } \\
\text { memiliki temapt pemancingan } \\
\text { ikan. }\end{array}$ \\
\hline
\end{tabular}

Tabel 2 Perkembangan UMKM Mina Kembar 
Perwira Journal of Science and Engineering (PJSE)

E-ISSN : 2775-8486

Volume 1 Nomor 1

Februari 2021

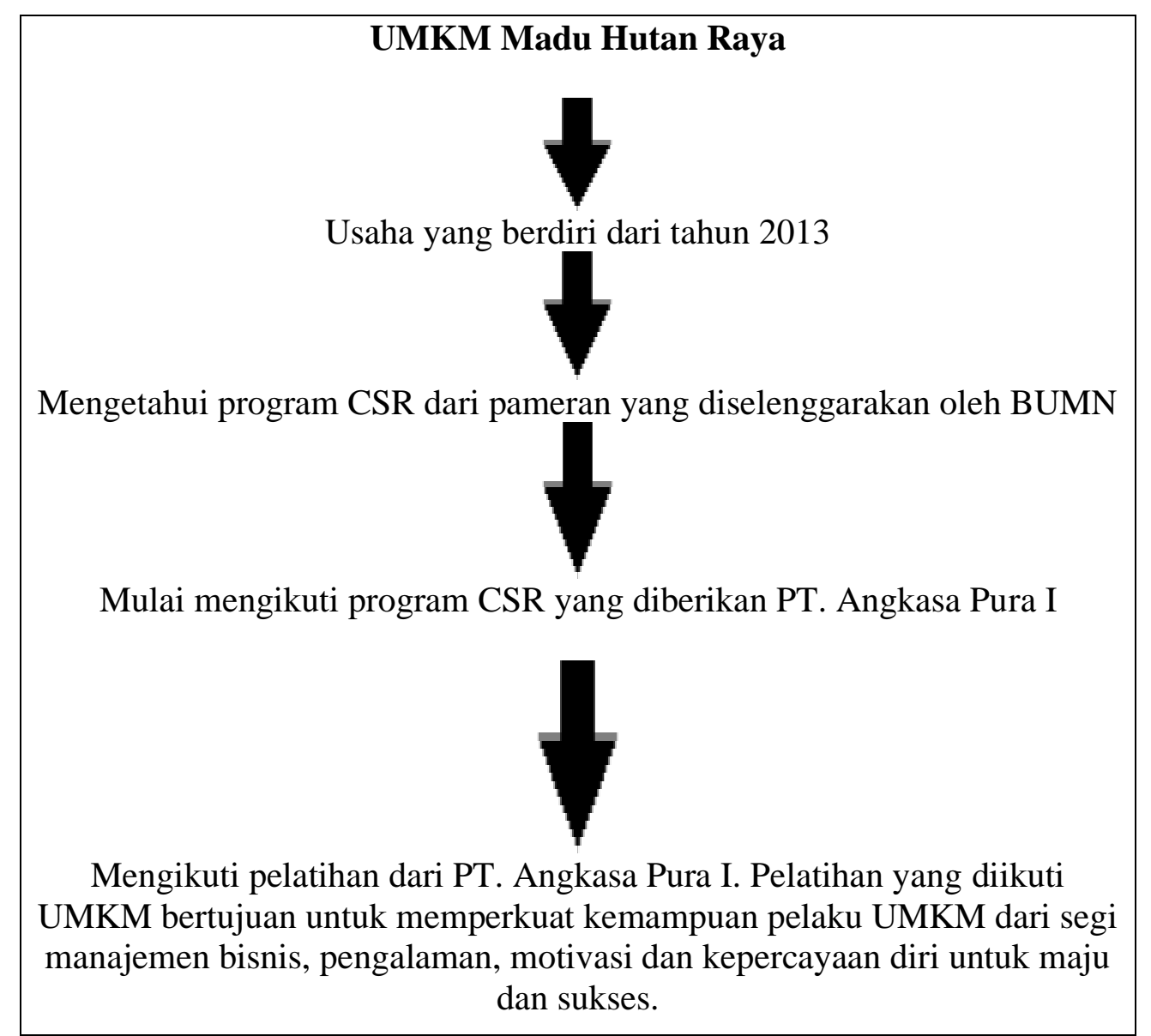

Gambar 1.3 Proses Pemberdayaan UMKM Madu Hutan Raya

\begin{tabular}{l|l|l}
\hline \multicolumn{1}{c|}{$\begin{array}{c}\text { Uraian } \\
\text { Pengetahuan } \\
\text { bisnis }\end{array}$} & $\begin{array}{l}\text { Sebelum Bergabung } \\
\text { wawasan masih belum } \\
\text { luas. }\end{array}$ & $\begin{array}{l}\text { Setelah Bergabung } \\
\text { Pelatihan yang dilakukan } \\
\text { oleh PT. Angkasa Pura I } \\
\text { dalam program CSR nya } \\
\text { sangat membantu dalam } \\
\text { hal mengembangkan jiwa, } \\
\text { keterampilan dan wawasan } \\
\text { sebagai pengusaha dan } \\
\text { menginspirasi beliau untuk } \\
\text { mengembangkan } \\
\text { produknya yaitu Madu } \\
\text { Hutan. }\end{array}$ \\
\hline
\end{tabular}


Perwira Journal of Science and Engineering (PJSE)

E-ISSN : 2775-8486

Volume 1 Nomor 1

Februari 2021

\begin{tabular}{l|l|l}
\hline $\begin{array}{l}\text { Pengemasan } \\
\text { dan pemasaran }\end{array}$ & $\begin{array}{l}\text { Proses pengemasan dan } \\
\text { promosinya pun masih } \\
\text { sangat sederhana } \\
\text { sehingga pendapatan } \\
\text { yang diperoleh hanya } \\
\text { sedikit dan sulit untuk } \\
\text { berkembang }\end{array}$ & $\begin{array}{l}\text { Usaha semakin } \\
\text { berkembang dari } \\
\text { pengemasan sudah } \\
\text { menarik dan promosi } \\
\text { sudah meluas. }\end{array}$ \\
$\begin{array}{l}\text { Pengetahuan } \\
\text { usaha }\end{array}$ & $\begin{array}{l}\text { Belum mengenal usaha } \\
\text { UMKM yang ada di } \\
\text { yogyakarta }\end{array}$ & $\begin{array}{l}\text { Menjadi mitra binaan PT. } \\
\text { Angkasa Pura I juga } \\
\text { menambah pengetahuan } \\
\text { bagi Bapak Waluyo } \\
\text { mengenai berbagai usaha }\end{array}$ \\
& $\begin{array}{l}\text { UMKM yang ada di } \\
\text { Yogyakarta, sehingga } \\
\text { semangat berwirausaha } \\
\text { akan semakin besar }\end{array}$ \\
& $\begin{array}{l}\text { Setelah menjadi mitra } \\
\text { binaan PT. Angkasa Pura I } \\
\text { perlahan tapi pasti dalam } \\
\text { mengembangkan } \\
\text { usahanya. }\end{array}$ \\
$\begin{array}{l}\text { Arah } \\
\text { Pengembangan } \\
\text { usaha }\end{array}$ & $\begin{array}{l}\text { di Kabupaten Sleman inga belum meliliki } \\
\text { tadingah pengembangan } \\
\text { asaha yang baik. }\end{array}$ & \\
\hline
\end{tabular}

Tabel 1.3 Perkembangan UMKM Madu Hutan Raya

\section{PEMBAHASAN}

Dalam program CSR yang dilaksanakan, terdapat pelatihan yang bertujuan untuk menguatkan UMKM dari segi manajemen, inovasi dan jiwa kewirausahaan para pelaku UMKM. PT. Angkasa Pura I menggandeng beberapa stakeholder terkait dalam pelaksanaan pelatihan, hal ini bertujuan agar para pelaku UMKM dapat dengan mudah menerima materi pelatihan. Jika dilihat dari perkembangan UMKM yang memanfaatkan program CSR maka proses pemberdayaan PT. Angkasa Pura I melalui program CSR yang diperuntukan kepada UMKM dapat dikatakan telah berhasil. Hal ini terlihat pada perkembangan UMKM Mina Kembar dan UMKM Madu Hutan Raya. Ada lima dasar teoritis yang memiliki agumentasi yang kuat bagi perusahaan untuk melaksanakan tanggung jawab sosialnya, yaitu:

\section{Teori Stakeholder}

Teori ini menyatakan bahwa kesuksesan dan hidup matinya suatu perusahaan sangat tergantung pada kemampuannya menyeimbangkan beragam kepentingan dari para stakeholderatau pemangku kepentingan. Dalam perspektif teori Stakeholder masyarakat dan lingkungan merupakan stakeholder inti perusahaan yang harus diperhatikan. 
Perwira Journal of Science and Engineering (PJSE)

E-ISSN : 2775-8486

Volume 1 Nomor 1

Februari 2021

\section{Teori Legitimasi (Legitimacy Theory)}

Dalam perspektif teori legitimasi, perusahaan dan komunitas sekitar memiliki relasi sosial yang erat karena kedudukannya terikat dalam suatu "social contract'Teori kontrak social menyatakan bahwa

keberadaan perusahaan dalam suatu area karena didukung secara politis dan dijamin oleh regulasi pemerintah serta parlemen yang juga merupakan representasi dari masyarakat. Dengan demikian, ada kontrak sosial secara tidak langsung antara perusahaan dan masyarakat dimana masyarakat memberi cost dan benefit untuk keberlanjutan suatu korporasi.

\section{Teori Sustaibilitas Korporasi (Corporate Sustainability Theory)}

Menurut teori ini, agar bisa hidup dan tumbuh secara berkelanjutan, korporasi harus mengintegrasikan tujuan bisnis dengan tujuan sosial dan ekologi secara utuh. Pembangunan bisnis harus berlandaskan pada tiga pilar utama yaitu ekonomi, sosial, dan lingkungan secara terpadu, serta tidak mengorbankan kepentingan generasi berikutnya untuk hidup dan memenuhi kehidupannya.

\section{Teori Political Economy}

Menurut teori ini, domain ekonomi tidak dapat diisolasikan dari lingkungan di mana transaksi-transaksi ekonomi dilakukan. Karena tidak dapat diisolasikan dengan masyarakat dan lingkungan, perusahaan wajib memperhatikan dan melaksanakan CSR.

\section{Teori Keadilan (Justice Theory)}

Menutur teori ini, dalam sosial kapitalis pasar bebas, laba/rugi sangat tergantung pada the unequal rewards and privilages yang terdapat dalam laba dan kompensasi. Laba/rugi menceminkan ketidakadilan antar pihak yang dinikmati atau diderita suatu perusahaan. Karena itu, perusahaan perusahaan harus adil terhadap masyarakat dan lingkungan sekitarnya yang sudah turut menanggung dampak eksternalitas perusahaan melalui program-program CSR.

Karena program CSR yang dilakukan oleh PT. Angkasa Pura I secara keseluruhan mengikuti pedoman yang sudah ada. Proses pelaksanaan program CSR berjalan secara terarah dan juga UMKM dapat menerima materi dengan mudah karena PT. Angkasa Pura I menggandeng stakeholder dalam pelaksanaan pelatihan. Namun hal ini juga berdampak pada kurang berkembangnya kreatifitas pelaku UMKM hal ini tentunya kurang sejalan dengan apa yang dikemukakan oleh Elkington (1997) CSR bermakna sebagai suatu komitmen perusahaan atau dunia bisnis untuk berkontribusi dalam pembangunan ekonomi secara berkesinambungan dengan menyelaraskan pencapaian kinerja ekonomi dengan kinerja sosial dan lingkungan dalam operasi bisnisnya. Berdasarkan teori tersebut dapat dikatakan dalam menyusun program CSR, sebaiknya perusahaan melibatkan calon penerima manfaat tidak hanya dalam proses pelatihan namun dapat juga menggandeng stakeholder lain dalam proses penentuan bentuk program dan sosialisasi program CSR.

\section{KESIMPULAN}

Proses pemberdayaan melalui program CSR yang dilaksanakan PT. Angkasa Pura I kepada UMKM telah dilaksanakan sesuai dengan aturan dan pedoman yang berlaku. Perkembangan UMKM yang memanfaatkan program CSR dari PT. Angkasa Pura I sudah 
Perwira Journal of Science and Engineering (PJSE)

E-ISSN : 2775-8486

Volume 1 Nomor 1

Februari 2021

berjalan dengan baik yang ditandai dengan mulai berkembangnya asset usaha hingga pola berfikir dalam berusaha.

SARAN

Aset usaha yang meningkat seharusnya diimbangi dengan peningkatan kualitas produk sehingga dapat lebih memuaskan konsumen. Peningkatan produk yang terjual juga harus dimanfaatkan untuk menambah inovasi produk baru agar dapat diminati kalangan yang berbeda.

\section{DAFTAR PUSTAKA}

Adisasmita, Rahardjo. 2006. Pembangunan Pedesaan dan Perkotaan. Yogyakarta: Graha Ilmu

Budiarto, Agus. 2002. Seri Hukum Perusahaan: Kedudukan Hukum dan TanggungJawab Pendiri Perseroan Terbatas. Jakarta: Ghalia Indonesia.

Budiyono, Tri. 2010. Hukum Perusahaan. Salatiga: Griya Media.

Business \& Biodiversity. 2002. The World Business Councilfor Sustainable Development The Handbook for Corporate Action, Earthwatch Europe, IUCN,

Elkington, John. 1997. Cannibals with forks, the triple bottom line of twentieth century business. Capstone Publishing Ltd, London.

Ginanjar Kartasasmita. 1996 Pemberdayaan Masyarakat: Konsep Pembangunan yang berakar pada Masyarakat, Jakarta: Bappenas.

Gunawan Sumodiningrat. 1999. Pemberdayaan Masyarakat dan Jaringan Pengaman Sosial, Jakrta: PT Gramedia Pustaka Utama

Lako, A. 2011. Dekonstruksi CSR dan Reformasi Paradigma Bisnis dan Akuntansi. Jakarta: Erlangga

Mardikanto, T. 2013. Pemberdayaan Masyarakat oleh Perusahaan: Corporate Social Responsibility: Acuan bagi Praktisi, Akademisi, dan Pemerhati Program CSR. Surakatra: Sebelas Maret University Press.

Miles, M. B., \& Huberman, A. M. 1994.Qualitative Data Analysis: An Expanded Sourcebook (2nd ed.). SAGE Publications.

Nuryana, Mu'man. 2005. Corporate Social Responsibility dan Kontribusi Bagi Pembangunan Berkelanjutan. Balai Besar Pendidikan dan Pelatihan Kesejahteraan Sosial (BBPPKS) Bandung.

Sugiyono. 2011. Metode Penelitian Kuantitatif, Kualitatif, dan $R$ \& D. Bandung: Alfabeta. 